\title{
PENGARUH KOMPETENSI, INDEPENDENSI, ETIKA, PENGALAMAN AUDITOR, DAN TEKANAN ANGGARAN WAKTU TERHADAP KUALITAS AUDIT
}

\author{
Stella Angelina \\ Universitas Multimedia Nusantara \\ stella_jtlover@yahoo.com
}

\begin{abstract}
The objective of this research is to examine the influence of auditor's competency, independency, ethic, experience, and time budget pressure toward audit quality. The object of this research is public accountants (external auditor) that working at Public Accounting Firm in Jakarta and Tangerang.

This research was conducted using a survey method. Data were collected using questionnaires. From 180 questionnaires distributed, 119 questionnaires were returned, and 28 questionnaires were not meet the criteria, so that only 91 questionnaire could be process. Data analysis conducted with multiple linear regression model.

The result of this study were competency, independency, ethic, experience, and time budget pressure have significant influence to audit quality simultaneously. Competency, independency, experience, and time budget pressure have significant influence to audit quality partially. But, ethic not have significant influence to audit quality partially.
\end{abstract}

Keywords: competency, independency, ethic, experience, time budget pressure, audit quality.

\section{PENDAHULUAN}

Kasus audit yang terjadi dalam beberapa tahun terakhir membuat kepercayaan masyarakat terhadap kualitas audit menurun. Masyarakat menjadi bertanyatanya mengenai kredibilitas profesi auditor. Pada beberapa kasus, auditor tidak dapat menemukan kecurangan dalam laporan keuangan, atau kecurangan tersebut telah ditemukan namun tidak dilaporkan oleh auditor. Seperti kasus yang terjadi pada PT Telkom dimana KAP Eddy Pianto tidak diakui oleh SEC. SEC tentunya memiliki alasan khusus mengapa KAP Eddy Pianto tidak diakui. Hal itu terkait dengan kompetensi dan independensi auditornya yang masih diragukan.

Pada kasus lainnya, ditemukan bahwa auditor diindikasi melakukan kerja sama dengan pihak manajemen klien untuk mengamankan praktik rekayasa laporan keuangan. Praktik rekayasa laporan keuangan seperti yang terjadi pada Enron yang melibatkan Kantor Akuntan Publik Arthur Andersen. Pada laporan keuangan, perusahaan dilaporkan mencatat keuntungan 600 juta Dollar AS, padahal sebenarnya perusahaan mengalami kerugian. Laporan keuangan Enron telah dinyatakan Wajar Tanpa Pengecualian 
oleh Kantor Akuntan Publik Arthur Andersen. Namun, publik kemudian dikejutkan oleh kabar kepailitan Enron pada tanggal 2 Desember 2001. Berdasarkan hasil pemeriksaan, ditemukan ternyata terdapat beberapa pejabat, manajer, dan sebagian besar staf akuntansi Enron adalah mantan auditor di KAP Arthur Andersen. Setelah kasus ini diungkap dan dilakukan penyelidikan, akhirnya KAP Arthur Andersen dinyatakan bersalah karena melakukan hambatan terhadap proses pengadilan melalui penghancuran dokumen-dokumen yang terkait dengan audit yang mereka lakukan.

Kasus-kasus audit yang telah terjadi membuat profesi auditor menjadi sorotan masyarakat. Sebagai pihak ketiga yang independen, auditor seharusnya bertanggung jawab untuk memberikan jaminan atas kehandalan dari laporan keuangan yang diaudit. Auditor melaksanakan audit bukan hanya untuk kepentingan klien, tetapi juga untuk kepentingan pihak lain atas laporan keuangan perusahaan. Pihak lain yang memiliki kepentingan pada perusahaan terdiri dari: pemilik perusahaan, karyawan, investor, kreditur, pemerintah, dan masyarakat umum. Auditor harus bersikap profesional dalam melaksanakan audit agar tidak ada pihak yang dirugikan karena telah mendapatkan kepercayaan dari publik.

Kepercayaan besar dari pengguna laporan keuangan yang diaudit mengharuskan akuntan publik (auditor) untuk memperhatikan kualitas audit yang dihasilkannya. Seorang auditor harus mempertahankan dan meningkatkan kualitas audit yang dimilikinya. Dalam upaya untuk terus meningkatkan kualitas auditnya, auditor diharapkan untuk terusmenerus mengikuti perkembangan dunia bisnis dan profesinya. Auditor harus memiliki sikap kritis dan rasa ingin tahu yang tinggi untuk terus meningkatkan keahlian profesionalnya. Namun, auditor seringkali dihadapkan pada 2 pilihan yang sulit sehingga mempengaruhi kualitas auditnya. Pertama, auditor dituntut untuk melaksanakan audit demi kepuasan kliennya. Kedua, auditor harus tetap menjunjung tinggi sikap profesionalnya dalam melaksanakan tanggung jawabnya tanpa memihak kepada pihak manapun (independensi) dan tetap menjaga kepentingan umum.

Angelo (1981) dalam Hutabarat (2012) mendefinisikan kualitas audit sebagai segala kemungkinan (probability) dimana auditor pada saat mengaudit laporan keuangan klien dapat menemukan pelanggaran yang terjadi dalam sistem akuntansi klien dan melaporkannya dalam 
laporan keuangan auditan, dimana dalam melaksanakan tugasnya tersebut auditor berpedoman pada standar auditing dan kode etik akuntan publik. Seorang auditor dituntut untuk menghasilkan kualitas pekerjaan yang tinggi karena auditor memiliki tanggung jawab yang besar terhadap pihak-pihak yang berkepentingan terhadap laporan keuangan perusahaan, termasuk investor dan masyarakat. Jasa auditor dibutuhkan untuk memberikan keyakinan yang memadai bahwa laporan keuangan telah disajikan secara wajar sehingga pengambilan keputusan para penggunanya dapat dilakukan dengan tepat.

Ilmiyati dan Suhardjo (2012) menyatakan bahwa dalam melakukan audit, seorang auditor harus memiliki mutu personal yang baik, pengetahuan yang memadai, serta keahlian khusus di bidangnya. Menurut Rai (2008) dalam Sukriah dkk. (2009), kompetensi auditor adalah kualifikasi yang dibutuhkan oleh auditor untuk melaksanakan audit dengan benar. Kompetensi berkaitan dengan keahlian profesional yang dimiliki oleh auditor sebagai hasil dari pendidikan formal, ujian profesional, serta keikutsertaaan dalam pelatihan, seminar, dan simposium. Kompetensi auditor yang semakin tinggi membuat kualitas audit semakin baik.
Selain memiliki kompetensi, auditor juga harus memiliki independensi, yaitu sikap yang diharapkan untuk tidak mempunyai kepentingan pribadi dalam pelaksanaan tugasnya, yang bertentangan dengan prinsip integritas dan objektivitas serta tidak mudah untuk dipengaruhi oleh orang lain (terutama klien) dalam menjalankan tugasnya. Dalam Kode Etik Akuntan Indonesia, dinyatakan bahwa setiap anggotanya harus mempertahankan integritas, objektifitas, dan independensi dalam melakukan tugasnya. Penelitian Marchelo (2010) dalam Rapina dkk. (2010) menyimpulkan bahwa audit forensik yang dilakukan KAP belum tentu bersifat independen. Beberapa faktor seperti adanya hubungan keluarga dengan klien, hubungan keuangan dengan klien, keuntungan dan kerugian terkait usaha dengan klien yang akan menyebabkan independensi auditor sulit depertahankan. Apabila auditor mampu mempertahankan independensinya, maka kualitas audit akan semakin baik.

Menurut Saputra (2012) dan Alim dkk. (2007), kompetensi dan independensi yang dimiliki auditor dalam penerapannya akan terkait dengan etika. Etika auditor merupakan nilai tingkah laku auditor untuk menumbuhkan kepercayaan publik terhadap organisasi dengan selalu berperilaku etis dan memegang prinsip 
etika yang baik. Pada saat pelaksanaan audit, beberapa auditor biasanya akan dihadapkan pada situasi konflik kepentingan terhadap kliennya sehingga menyebabkan terjadinya pelanggaran terhadap kode etik profesi akuntan. Konflik kepentingan dimana auditor cenderung menerima seluruh permintaan klien (misalnya, tidak melaporkan kecurangan klien) demi kepuasan klien dan mendapatkan fee sehingga menjadi tidak independen. Dalam menjalankan praktik profesinya, auditor harus mematuhi kode etik profesi yang mengatur perilakunya. Auditor yang selalu patuh terhadap kode etik profesi akan mampu meningkatkan kualitas auditnya.

Selain kompetensi, independensi, dan etika, pengalaman kerja auditor juga dipandang sebagai salah satu faktor yang mempengaruhi kualitas audit. Pengalaman kerja merupakan salah satu persyaratan dalam memperoleh izin Akuntan Publik. Menurut Libby dan Frederick (1990) dalam Hutabarat (2012), semakin banyak pengalaman auditor, semakin dapat menghasilkan berbagai dugaan dalam menjelaskan temuan audit. Penelitian Noviyanti dalam Tuanakotta (2011) menjelaskan bahwa auditor yang berpengalaman menunjukkan skeptisme professional yang lebih tinggi dibandingkan dengan auditor yang tidak berpengalaman. Pengalaman yang dimiliki oleh auditor akan meningkatkan kualitas auditnya.

Faktor lainnya yang mempengaruhi kualitas audit adalah tekanan anggaran waktu (time budget pressure). Tuntutan laporan yang berkualitas dengan anggaran waktu terbatas merupakan tekanan tersendiri bagi auditor sehingga terkadang auditor terlalu percaya kepada penjelasan dan presentasi klien serta gagal mengumpulkan bukti-bukti terkait pelanggaran klien. Hal ini menyebabkan auditor menghasilkan laporan audit dengan kualitas yang rendah. Tekanan anggaran waktu yang semakin ketat akan menyebabkan kualitas audit menurun.

Penelitian terdahulu yang dilakukan oleh Hutabarat (2012) menunjukkan bahwa pengalaman audit, time budget pressure, dan etika auditor secara simultan berpengaruh signifikan terhadap kualitas audit. Pengalaman audit memberikan pengaruh positif yang signifikan terhadap kualitas audit, yaitu semakin tinggi pengalaman audit, maka akan memberikan dampak positif terhadap peningkatan kualitas audit. Time budget pressure (tekanan anggaran waktu) berpengaruh negatif signifikan terhadap kualitas audit, yaitu semakin tinggi tekanan anggaran waktu, maka akan berpengaruh terhadap penurunan kualitas 
audit. Etika auditor berpengaruh positif signifikan terhadap kualitas audit, yaitu semakin tinggi etika auditor, maka akan berpengaruh terhadap meningkatnya kualitas audit.

Penelitian ini merupakan replikasi dari penelitian Hutabarat (2012) dengan pengembangan sebagai berikut: (1) menambahkan dua variabel independen, yaitu kompetensi dan independensi dan (2) objek penelitian adalah auditor yang bekerja dalam KAP di Jakarta dan Tangerang.

Oleh karena itu, berdasarkan uraian di atas, maka judul peneltian ini adalah "Pengaruh Kompetensi, Independensi, Etika, Pengalaman Auditor, dan Tekanan Anggaran Waktu terhadap Kualitas Audit".

\section{TELAAH LITERATUR}

Kompetensi Auditor

Kompetensi merupakan kecakapan dan kemampuan seseorang dalam menjalankan suatu pekerjaan atau profesi. Dalam, standar umum ketiga menyebutkan bahwa dalam pelaksanaan audit dan penyusunan laporannya, auditor wajib menggunakan kemahiran profesionalnya dengan cermat dan seksama. Anggota Kantor Akuntan Publik hanya boleh melakukan pemberian jasa profesional yang diharapkan dapat diselesaikan dengan kompetensi profesional.

Indikator yang digunakan untuk mengukur kompetensi adalah mutu personal, pengetahuan umum, dan keahlian khusus (Sukriah dkk., 2009). Penelitian Ilmiyati dan Suhardjo (2012), Alim dkk. (2007), Sukriah dkk. (2009), dan Saputra (2012) menunjukkan bahwa kompetensi berpengaruh terhadap kualitas audit. Semakin tinggi kompetensi auditor, semakin baik kualitas auditnya. Sedangkan, penelitian Samsi dkk. (2013) menunjukkan bahwa kompetensi auditor tidak berpengaruh terhadap kualitas audit.

Jadi, dapat disimpulkan bahwa kompetensi auditor merupakan kemampuan profesional yang dimiliki oleh auditor dari pendidikan formal, pengalaman dalam praktik, dan menjalani pelatihan teknis yang cukup. Pengetahuan auditor yang didapatkan dari pendidikan formal, pembelajaran melalui pengalaman, dan pelatihan teknis diharapkan menambah kemampuan atau kompetensinya di bidang auditing sehingga dapat meningkatkan kualitas audit. 


\section{Ha 1 Kompetensi Auditor berpengaruh terhadap Kualitas Audit.}

Independensi Auditor

Standar Umum Auditing yang kedua menyatakan bahwa dalam semua hal yang berhubungan dengan perikatan, independensi dalam sikap mental harus dipertahankan oleh auditor. Pernyataan Etika Profesi Nomor 1 (Pendahuluan) menjelaskan bahwa independensi adalah sikap yang diharapkan dari seorang auditor (akuntan publik) untuk tidak mempunyai kepentingan pribadi dalam pelaksanaan tugasnya, yang bertentangan dengan prinsip integritas dan objektivitas.

Indikator yang digunakan untuk mengukur independensi sebagai berikut (Putra, 2012): hubungan dengan klien, independensi pelaksanaan pekerjaan, dan independensi pelaporan. Rapina dkk. (2010), Alim dkk. (2007), Saputra (2012), dan Samsi dkk. (2010) menemukan bahwa independensi berpengaruh signifikan terhadap kualitas audit. Sedangkan, penelitian Sukriah dkk. (2009), Queena dan Rohman (2012) menemukan bahwa independensi tidak berpengaruh signifikan terhadap kualitas hasil pemeriksaan.

Jadi, dapat disimpulkan bahwa independensi auditor adalah suatu sikap dimana seorang auditor tidak mudah untuk dipengaruhi dan tidak memihak ke pihak manapun serta tidak memiliki kepentingan pribadi saat melaksanakan tugasnya. Auditor tidak boleh mudah dipengaruhi oleh pihak manapun dalam pelaksanaan auditing karena merupakan pihak ketiga yang independen. Untuk menjaga independensinya, auditor tidak boleh memiliki hubungan keluarga atau bisnis dengan kliennya. Auditor yang mampu mempertahankan independensinya diharapkan akan memberikan kualitas audit yang baik.

\section{Ha2: Independensi Auditor berpengaruh terhadap Kualitas Audit.}

Etika Auditor

Etika auditor merupakan nilai tingkah laku auditor untuk menumbuhkan kepercayaan publik terhadap organisasi dengan selalu berperilaku etis dan memegang prinsip etika yang baik. Auditor harus mematuhi Kode Etik yang ditetapkan dalam pelaksanaan tugas dan tanggung 
jawabnya. Kode etik profesi diperlukan untuk menjaga martabat serta kehormatan profesi, dan di sisi lain, untuk melindungi masyarakat dari segala bentuk penyimpangan maupun penyalahgunaan keahlian.

Indikator yang digunakan untuk mengukur etika auditor sebagai berikut (Putra, 2012): tanggung jawab profesi auditor, integritas, dan objektivitas. Audit yang berkualitas sangat penting untuk menjamin bahwa profesi akuntan memenuhi tanggung jawabnya kepada investor, masyarakat umum dan pemerintah serta pihakpihak lain yang mengandalkan kredibilitas laporan keuangan yang telah diaudit, dengan menegakkan etika yang tinggi (Widagdo dkk., 2002 dalam Alim dkk., 2007 dan Samsi dkk., 2013). Lubis (2009) dalam Samsi dkk. (2013) menyatakan bahwa kepatuhan pada kode etik yang baik/tinggi akan berpengaruh terhadap kualitas auditor yang baik/tinggi. Penelitian Hutabarat (2012), Queena dan Rohman (2012) menunjukkan bahwa etika berpengaruh terhadap kualitas audit.

Jadi, dapat disimpulkan bahwa etika auditor adalah perilaku dimana auditor dalam menjalankan tugas dan tanggung jawabnya sesuai dengan kode etik profesi yang ditetapkan sehingga dapat menjaga kepercayaan publik. Auditor yang patuh dengan kode etik dalam pelaksanaan audit diharapkan akan meningkatkan kualitas auditnya.

\section{Ha $:$ Etika Auditor berpengaruh terhadap Kualitas Audit.}

\section{Pengalaman Auditor}

Standar Umum Auditing yang pertama menyatakan bahwa audit harus dilaksanakan oleh seorang atau lebih yang memiliki keahlian dan pelatihan teknis yang cukup sebagai auditor. Standar umum tersebut menegaskan bahwa tingginya kemampuan seseorang di bidang-bidang lain, termasuk bidang bisnis dan keuangan tidak cukup untuk dapat memenuhi syarat dalam standar auditing ini apabila tidak memiliki pendidikan dan pengalaman yang memadai dalam bidang auditing. Hal ini berarti untuk melakukan audit yang berkualitas, diperlukan keahlian dan profesionalisme yang tinggi.

Pengalaman akan membentuk keahlian seseorang, baik secara teknis maupun secara psikis. Pendidikan formal dan pengalaman auditor saling melengkapi satu sama lain. Pengalaman profesional diperoleh dari 
praktik kerja di bawah bimbingan atau supervisi dari auditor yang lebih senior. Pengalaman auditor akan semakin berkembang dengan bertambahnya pengalaman audit, diskusi mengenai audit dengan rekan sekerja, pengawasan dan review oleh akuntan senior, mengikuti program pelatihan, dan penggunaan standar auditing (Butt, 1988; Tubbs, 1992; Bonner, 1990 dalam Hutabarat, 2012). Indikator yang digunakan untuk mengukur pengalaman sebagai berikut (Sukriah dkk., 2009): lamanya bekerja sebagai auditor dan banyaknya tugas pemeriksaan.

Menurut Libby dan Trotman (2002) dalam Queena dan Rohman (2012), seorang auditor profesional harus mempunyai pengalaman yang cukup tentang tugas dan tanggung jawabnya. Pengalaman auditor akan menjadi bahan pertimbangan yang baik dalam mengambil keputusan dalam tugasnya. Dalam Hutabarat (2012), Abdolmohammadi dan Wright (1987) memberikan bukti empiris bahwa dampak pengalaman auditor akan signifikan terhadap kualitas kinerja auditor. Penelitian Sukriah dkk. (2009) menunjukkan adanya pengaruh pengalaman kerja terhadap kualitas audit.
Jadi, dapat disimpulkan bahwa pengalaman auditor merupakan suatu proses dimana auditor memiliki pengetahuan lebih mendalam tentang audit yang diperolehnya dari praktik kerja di bawah bimbingan (supervisi) auditor yang lebih senior dan pembelajaran dari tugas audit yang telah dilakukan di periode audit lalu. Pengalaman auditor semakin bertambah seiring dengan semakin lamanya bekerja sebagai auditor dan banyaknya penugasan yang ditanganinya sehingga diharapkan kualitas audit yang dihasilkannya semakin tinggi.

\section{Ha $:$ Pengalaman Auditor berpengaruh terhadap Kualitas Audit.}

\section{Tekanan Anggaran Waktu}

Dezoort (2002) dalam Prasita dan Adi (2007) mendefinisikan tekanan anggaran waktu sebagai bentuk tekanan yang muncul dari keterbatasan sumber daya yang dapat diberikan untuk melaksanakan tugas. Sumber daya dapat diartikan sebagai waktu yang digunakan auditor dalam pelaksanaan tugasnya. Indikator yang digunakan untuk mengukur tekanan anggaran waktu sebagai berikut (Putra, 2012): sikap auditor 
memanfaatkan waktu audit dan sikap auditor dalam penurunan kualitas audit.

Kantor Akuntan Publik harus mampu mengalokasikan waktu secara tepat sehingga dapat menentukan besarnya audit fee. Alokasi waktu yang terlalu lama dapat berarti audit fee yang semakin besar dan klien akan menanggung audit fee yang besar. Hal ini bisa menjadi kontraproduktif mengingat ada kemungkinan klien memilih menggunakan Kantor Akuntan Publik lain yang lebih kompetitif. Waktu pengauditan harus dialokasikan secara realistis, tidak terlalu lama atau terlalu cepat. Riset sebelumnya yang dilakukan oleh Hutabarat (2012) dan Coram dkk. (2003) dalam Prasita dan Adi (2007) menunjukkan bahwa terdapat penurunan kualitas audit saat auditor mengalami tekanan anggaran waktu yang sangat ketat.

Jadi, dapat disimpulkan bahwa tekanan anggaran waktu adalah suatu kondisi dimana seorang auditor harus melakukan efisiensi terhadap adanya keterbatasan waktu saat melakukan audit agar besarnya audit fee tidak terlalu besar. Keterbatasan waktu audit akan meningkatkan stres auditor. Auditor harus menyelesaikan tugastugas yang kompleks dan menyampaikan laporan secara tepat waktu atau sesuai dengan anggaran waktu yang telah ditetapkan. Tekanan anggaran waktu yang ketat akan membuat kualitas audit yang dihasilkan menjadi rendah.

\section{Ha5: Tekanan Anggaran Waktu berpengaruh terhadap Kualitas Audit.}

\section{Model Penelitian}

Berdasarkan teori di atas, maka model dalam penelitian ini adalah kompetensi auditor, independensi auditor, etika auditor, pengalaman auditor, dan tekanan anggaran waktu memiliki pengaruh terhadap kualitas audit. Model penelitian dapat digambarkan sebagai berikut: 


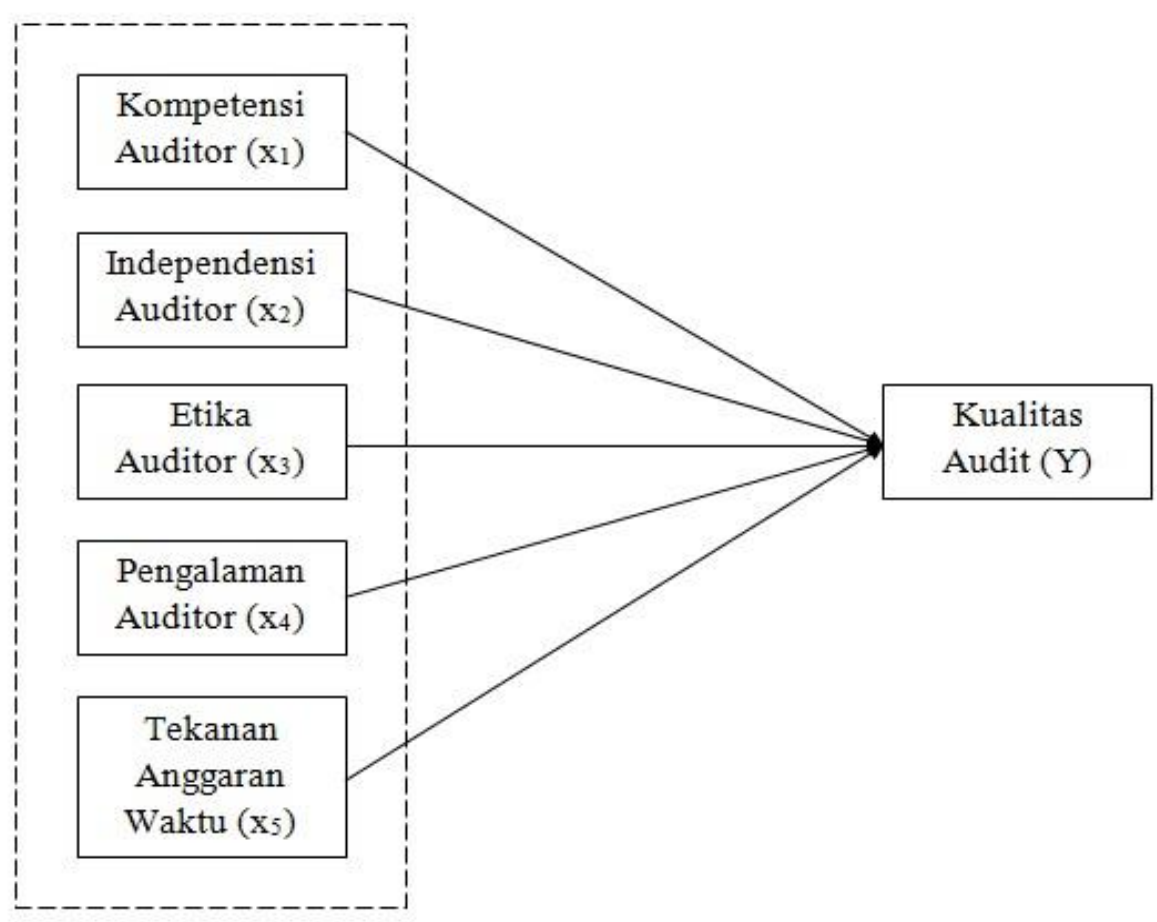

Gambar 1. Kerangka Penelitian

\section{METODOLOGI PENELITIAN}

Objek dalam penelitian ini adalah auditor yang bekerja di Kantor Akuntan Publik (KAP) yang berada di Jakarta dan Tangerang, dengan tingkat pendidikan terakhir minimal S1 dan minimal masa kerja 1 tahun. Auditor yang menjadi responden dalam penelitian ini, terdiri dari junior auditor, senior auditor, manajer, supervisor, dan partner. Jenis penelitian ini adalah causal study, yaitu penelitian yang melihat hubungan sebab akibat (melihat adanya tidaknya pengaruh) antar variabel-variabel penelitian.
Penelitian dilakukan untuk membuktikan hubungan sebab akibat (pengaruh) kompetensi auditor, independensi auditor, etika auditor, pengalaman auditor, dan tekanan anggaran waktu terhadap kualitas audit. Penelitian ini menggunakan metode pengumpulan data primer, yaitu data yang diperoleh langsung dari subjek atau objek peneliti melalui penyebaran kuesioner. Penyebaran kuesioner dilakukan dengan cara mendatangi langsung Kantor Akuntan Publik yang bersangkutan dan sebagian melalui perantara. 


\section{HASIL \& ANALISIS}

Uji Kualitas Data

Pengujian validitas menunjukkan bahwa variabel kompetensi, independensi, etika, pengalaman, tekanan anggaran waktu, dan kualitas audit memiliki sig (2-tailed) sebesar 0,000 atau lebih kecil dari 0,05. Hal ini menunjukkan bahwa semua pernyataan pada keenam variabel tersebut adalah valid. Pengujian reliabilitas dilakukan dengan menggunakan Cronbach's Alpha $(\alpha)$. Keenam variabel yang diuji memiliki nilai Cronbach's Alpha $(\alpha)$ di atas 0,70 , maka semua pernyataan tersebut dapat dikatakan reliable.

\section{Uji Hipotesis}

Dari hasil pengujian koefisien determinasi, didapatkan nilai $\mathrm{R}$ sebesar 0,773 . Nilai ini berada di atas 0,50 . Hal ini berarti terdapat hubungan yang kuat antara kualitas audit dengan kompetensi, independensi, etika, pengalaman, dan tekanan anggaran waktu. Selain itu, didapat nilai Adjusted $R$ square sebesar 0,574. Hal ini berarti $57,4 \%$ variabel kualitas audit dijelaskan oleh kelima variabel independen, yaitu kompetensi, independensi, etika, pengalaman, dan tekanan anggaran waktu. Sedangkan, sisanya sebesar $42,6 \% \quad(100 \% \quad-$ $57,4 \%$ ) dijelaskan oleh variabel lain di luar model.

Dari hasil uji ANOVA, didapat nilai $\mathrm{F}$ hitung sebesar 25,220 dengan tingkat signifikansi 0,000 atau $<0,05$. Hasil penelitian ini menunjukkan bahwa model regresi dapat digunakan untuk memprediksi kualitas audit atau dapat dikatakan bahwa kelima variabel independen, yaitu kompetensi, independensi, etika, pengalaman, dan tekanan anggaran waktu secara bersama-sama (simultan) berpengaruh signifikan terhadap kualitas audit. Kompetensi yang dimiliki oleh auditor dengan didukung oleh kemampuannya untuk mempertahankan independensi dan selalu memegang teguh etika akan meningkatkan kualitas audit. Selain itu, ditambah dengan pengalaman auditor yang semakin banyak dan kemampuannya menghadapi tekanan anggaran waktu juga akan membuat kualitas audit semakin baik. Berdasarkan hasil uji $\mathrm{F}$, maka $\mathrm{Ha}_{6}$ diterima.

Hasil penelitian ini sejalan dengan penelitian Hutabarat (2012) menunjukkan bahwa pengalaman audit, time budget pressure, dan etika 
auditor secara simultan berpengaruh terhadap kualitas audit. Hasil penelitian ini juga mendukung penelitian Sukriah dkk. (2009) juga menunjukkan bahwa terdapat pengaruh pengalaman kerja, independensi, objektifitas, integritas, dan kompetensi auditor secara simultan terhadap kualitas hasil pemeriksaan. Selain itu, hasil penelitian ini juga sejalan dengan penelitian Singgih dan Bawono (2010) yang menunjukkan bahwa independensi, pengalaman, due professional care, dan akuntabilitas berpengaruh secara simultan terhadap kualitas audit.

Dari pengujian statistik $t$ dapat diperoleh persamaan regresi sebagai berikut:

$$
Y=1,203+0,355 X_{1}+0,333 X_{2}+0,183 X_{3}+0,337 X_{4}-0,307 X_{5}
$$

Di mana:

$$
\begin{aligned}
\mathrm{Y} & =\text { kualitas audit } \\
\mathrm{a} & =\text { konstanta } \\
\mathrm{b} & =\text { koefisien regresi linear } \\
\mathrm{x}_{1} & =\text { kompetensi }
\end{aligned}
$$

\section{Berdasarkan persamaan regresi} yang dihasilkan, variabel kompetensi memiliki koefisien regresi sebesar 0,355. Hal ini berarti bahwa setiap kenaikan satu satuan kompetensi, maka akan terjadi peningkatan kualitas audit sebesar 0,355. Dari hasil uji statistik t, variabel kompetensi memiliki nilai t hitung sebesar 4,320 dengan tingkat signifikansi sebesar 0,000 atau lebih kecil dari 0,05. Hal ini berarti bahwa $\mathrm{Ha}_{1}$ diterima sehingga variabel kompetensi

$$
\begin{aligned}
& \mathrm{x}_{2}=\text { independensi } \\
& \mathrm{x}_{3}=\text { etika } \\
& \mathrm{x}_{4}=\text { pengalaman } \\
& \mathrm{x}_{5}=\text { tekanan anggaran waktu }
\end{aligned}
$$

memiliki pengaruh signifikan terhadap kualitas audit.

$$
\text { Variabel independensi }
$$
memiliki koefisien regresi sebesar 0,333. Hal ini berarti bahwa setiap kenaikan satu satuan independensi, maka akan terjadi peningkatan kualitas audit sebesar 0,333. Variabel independensi memiliki nilai t hitung sebesar 2,684 dengan tingkat signifikansi sebesar 0,009 atau lebih kecil dari 0,05. Hal ini berarti bahwa $\mathrm{Ha}_{2}$ diterima sehingga variabel 
independensi memiliki pengaruh signifikan terhadap kualitas audit.

$$
\text { Variabel etika memiliki }
$$

koefisien regresi sebesar 0,183 . Hal ini berarti bahwa setiap kenaikan satu satuan etika, maka akan terjadi penurunan kualitas audit sebesar 0,183 . Variabel etika memiliki nilai $\mathrm{t}$ hitung sebesar 1,520 dengan tingkat signifikansi sebesar 0,132 atau lebih besar dari 0,05 . Hal ini berarti bahwa $\mathrm{Ha}_{3}$ ditolak sehingga variabel etika tidak memiliki pengaruh signifikan terhadap kualitas audit.

Variabel pengalaman memiliki koefisien regresi sebesar 0,337. Hal ini berarti bahwa setiap kenaikan satu satuan pengalaman, maka akan terjadi peningkatan kualitas audit sebesar 0,337. Variabel pengalaman memiliki nilai t hitung sebesar 2,455 dengan tingkat signifikansi sebesar 0,016 atau lebih kecil dari 0,05. Hal ini berarti bahwa $\mathrm{Ha}_{4}$ diterima sehingga variabel pengalaman memiliki pengaruh signifikan terhadap kualitas audit.

$$
\text { Variabel tekanan anggaran }
$$
waktu memiliki koefisien regresi sebesar -0,307. Hal ini berarti bahwa setiap penambahan satu satuan tekanan anggaran waktu, maka akan terjadi penurunan kualitas audit sebesar 0,307. Variabel tekanan anggaran waktu memiliki nilai $\mathrm{t}$ hitung sebesar -3,461 dengan tingkat signifikansi sebesar 0,001 atau lebih kecil dari 0,05. Hal ini berarti bahwa $\mathrm{Ha}_{5}$ diterima sehingga variabel tekanan anggaran waktu memiliki pengaruh signifikan terhadap kualitas audit.

\section{KESIMPULAN}

Kesimpulan yang diperoleh dari penelitian ini adalah:

1. Kompetensi memiliki pengaruh signifikan terhadap kualitas audit. Hal ini dibuktikan dengan nilai $\mathrm{t}$ hitung sebesar 4,320 dan tingkat signifikansi sebesar 0,000 atau $<0,05$ sehingga $\mathrm{Ha}_{1}$ diterima. Maka, dapat disimpulkan bahwa semakin tinggi kompetensi auditor, akan semakin baik kualitas auditnya.

2. Independensi memiliki pengaruh signifikan terhadap kualitas audit. memiliki koefisien regresi sebesar 0,333. Hal ini dibuktikan dengan nilai t hitung sebesar 2,684 dan tingkat signifikansi sebesar 0,009 atau $<0,05$ sehingga $\mathrm{Ha}_{2}$ diterima. Maka, dapat disimpulkan bahwa semakin 
tinggi tingkat independensi yang dimiliki auditor, kualitas audit semakin baik.

3. Etika tidak memiliki pengaruh signifikan terhadap kualitas audit. Hal ini dibuktikan dengan nilai $\mathrm{t}$ hitung sebesar 1,520 dan tingkat signifikansi sebesar 0,132 atau $>0,05$ sehingga $\mathrm{Ha}_{3}$ ditolak.

4. Pengalaman memiliki pengaruh signifikan terhadap kualitas audit. Hal ini dibuktikan dengan nilai $\mathrm{t}$ hitung sebesar 2,455 dan tingkat signifikansi sebesar 0,016 atau $<0,05$ sehingga $\mathrm{H}_{\mathrm{a} 4}$ diterima. Maka, dapat disimpulkan bahwa semakin banyak pengalaman auditor, maka semakin baik kualitas auditnya.

5. Tekanan anggaran waktu memiliki pengaruh signifikan terhadap kualitas audit. Hal ini dibuktikan dengan nilai t hitung sebesar $-3,461$ dan tingkat signifikansi sebesar 0,001 atau $<0,05$ sehingga $\mathrm{Ha}_{5}$ diterima. Maka, dapat disimpulkan bahwa tekanan anggaran waktu menunjukkan pengaruh yang negatif. Auditor melakukan efisiensi waktu untuk mencapai batas waktu (deadline) yang sudah ditetapkan. Hal ini berarti tekanan anggaran waktu yang ketat membuat kualitas audit menurun.

6. Kompetensi, independensi, etika, pengalaman, dan tekanan anggaran waktu secara bersama-sama (simultan) berpengaruh signifikan terhadap kualitas audit. Dari hasil uji ANOVA, didapat nilai F hitung sebesar 25,220 dengan tingkat signifikansi 0,000 atau $<0,05$ sehingga $\mathrm{Ha}_{6}$ diterima. Maka, dapat disimpulkan bahwa kompetensi yang dimiliki oleh auditor dengan didukung oleh kemampuannya untuk mempertahankan independensi dan selalu memegang teguh etika akan meningkatkan kualitas audit. Selain itu, ditambah dengan pengalaman auditor yang semakin banyak dan kemampuannya menghadapi tekanan anggaran waktu juga akan membuat kualitas audit semakin baik. 


\section{Keterbatasan}

Beberapa keterbatasan dalam penelitian ini sebagai berikut:

1. Jumlah responden yang digunakan hanya 91 responden sehingga tidak dapat mengeneralisasi penelitian terhadap auditor yang bekerja pada Kantor Akuntan Publik (KAP) di Jakarta dan Tangerang.

2. Pendistribusian kuesioner dalam penelitian ini dilakukan pada saat responden sedang dalam masa sibuk (peak season) sehingga respon dari auditor menjadi rendah.

3. Responden penelitian ini sebagian besar merupakan junior auditor.

4. Nilai Adjusted $R$ Square yang diperoleh dari penelitian ini hanya sebesar $57,4 \%$ kualitas audit dijelaskan oleh kompetensi, independensi, etika, pengalaman, dan tekanan anggaran waktu. Sedangkan, sisanya sebesar $42,6 \%$ kualitas audit dipengaruhi oleh variabel independen lain di luar model.

5. Kedua indikator yang digunakan untuk mengukur variabel tekanan anggaran waktu tidak searah sehingga dapat membuat hasil penelitian menjadi bias.

\section{Saran}

Saran-saran yang diberikan atas keterbatasan dalam penelitian ini adalah:

1. Peneliti selanjutnya dapat meneliti dengan jumlah responden yang lebih banyak dengan menambah jumlah kuesioner yang disebarkan dan menambah jumlah KAP.

2. Pendistribusian kuesioner sebaiknya dilakukan pada saat responden tidak dalam masa sibuk (low season) sehingga respon dari para auditor lebih baik lagi.

3. Penelitian selanjutnya diharapkan dapat memperoleh responden dari semua jenjang jabatan sehingga penelitian ini dapat lebih baik.

4. Peneliti selanjutnya dapat menambah variabel independen lainnya yang dapat memepengaruhi kualitas audit, seperti akuntabilitas, integritas, objektivitas, dan due professional care. 
5. Untuk penelitian selanjutnya, kedua indikator variabel tekanan anggaran waktu dijadikan 2 variabel independen yang berbeda, yaitu sikap auditor dalam memanfaatkan waktu audit dan sikap auditor dalam penurunan kualitas audit.

\section{DAFTAR PUSTAKA}

Agoes, Sukrisno. 2012. Auditing. Jakarta: Lembaga Penerbit Fakultas Ekonomi Universitas Indonesia.

Alim, M.N., dkk. 2007. "Pengaruh Kompetensi dan Independensi terhadap Kualitas Audit dengan Etika Auditor Sebagai Variabel Moderasi". Simposium Nasional Akuntansi X, Unhas Makassar, 2628 Juli 2007.

Ayuningtyas, Harvita Yulian dan Sugeng Pamudji. 2012. "Pengaruh Pengalaman Kerja, Independensi, Obyektivitas, Integritas, dan Kompetensi terhadap Kualitas Hasil Audit". Diponegoro Journal of Accounting. Vol. 1 No. 2.

Elder, Randal J., dkk. 2011. Jasa Audit dan Assurance. Jakarta: Salemba Empat.

Ghozali, Imam. 2011. Aplikasi Analisis Multivariate dengan Program SPSS. Semarang: Badan Penerbit Universitas Diponegoro.
Hudiwinarsih, Gunasti. 2010. "Auditors' Experience, Competency, and Their Independency as the Influencial Factors in Professionalism". Journal of Economics, Business and Accountancy Ventura. Vol. 13 No. 3.

Hutabarat, Goodman. 2012. "Pengaruh Pengalaman Time Budget Pressure dan Etika Auditor terhadap Kualitas Audit". Jurnal Ilmiah ESAI. Vol. 6 No. 1. Januari 2012.

Institut Akuntan Publik Indonesia. 2011. Standar Profesional Akuntan Publik. Jakarta: Salemba Empat.

Ilmiyati, Feny dan Yohanes Suhardjo. 2012. "Pengaruh Akuntabilitas dan Kompetensi Auditor terhadap Kualitas Audit”. JURAKSI. Vol. 1 No. 1. Januari 2012.

Jelic, Milos. 2012. "The Impact of Ethics on Quality Audit Results". International Journal for Quality Research. Vol. 6 No. 4.

Pamungkas, Bayu. 2010. Pengaruh Time Budget Pressure, Pertimbangan Tingkat Materialitas, dan Audit Fee terhadap Kualitas Audit. Skripsi. Universitas Muhammadiyah, Yogyakarta.

Kementerian Keuangan. Peraturan Menteri Keuangan Nomor 17/PMK.01/2008 tentang Jasa Akuntan Publik.

Prasita, Andin dan Priyo Hari Adi. 2007. "Pengaruh Kompleksitas Audit dan Tekanan Anggaran Waktu terhadap Kualitas Audit dengan Moderasi Pemahaman terhadap Sistem Informasi”. Jurnal Ekonomi dan Bisnis. Fakultas Ekonomi Universitas Kristen Satya Wacana. September 2007. 
Queena, Precilia Prima dan Abdul Rohman. 2012. "Analisis FaktorFaktor yanhg Mempengaruhi Kualitas Audit Aparat Inspektorat Kota/Kabupaten di Jawa Tengah". Diponegoro Journal of Accounting. Vol. 1 No. 2.

Rapina, dkk. 2010. "Pengaruh Independensi Eksternal Auditor terhadap Kualitas Pelaksanaan Audit". Akurat: Jurnal Ilmiah Akuntansi No.2 Tahun ke-1. MeiAgustus 2010.

Samsi, Nur, dkk. 2013. "Pengaruh Pengalaman Kerja, Independensi, dan Kompetensi Auditor terhadap Kualitas Audit: Etika Auditor sebagai Variabel Pemoderasi". Jurnal Ilmu dan Riset Akuntansi. Vol. 1 No. 2.

Saputra, Anton Eka. 2012. "Pengaruh Kompetensi dan Independensi terhadap Kualitas Audit dengan Etika Auditor Sebagai Variabel Moderasi”. JURAKSI. Vol. 1 No. 2. Februari 2012.
Sekaran, Uma dan Roger Bougie. 2010. Research Method for Business: A Building Approach. Edisi 5. New York: John Willey \& Sons Ltd.

Singgih, Elisha Muliani dan Icuk Rangga Bawono. 2010. Pengaruh Independensi, Pengalaman, Due Professional Care, dan Akuntanbilitas terhadap Kualitas Audit. Simposium Nasional Akuntansi XIII. Purwokerto.

Suhayati, Ely. 2012. "The Influence of Audit Fee, Audit Time Budget Pressure and Public Accountant Attitude on the Public Accountant Dysfunctional Behavior and It's Implication on Audit Quality: Survey on Small Scale Public Accounting Firm's in Java". International Conference on Business and Economic Research.

Sukriah, dkk. 2009. "Pengaruh Pegalaman Kerja, Independensi, Obyektifitas, Integritas dan Kompetensi terhadap Kualitas Hasil Pemeriksaan". Simposium Nasional Akuntansi XII. Palembang. 